tylvinblastine-3-oic acid in biological fluids. J Chromatogr 1991;553:47-53.

- van Tellingen O, Beijnen JH, Nooijen WJ. Analytical methods for the determination of vinca alkaloids in biological speci mens: a survey of the literature. J Pharm Biomed Anal 1991 9:1077-82

- Oosterkamp HM, Vlasveld LT, Wanders J, Beijnen JH, van Tellingen $\mathrm{O}$, Dubbelman AC, et al. Phase I study of vintriptol a tryptophan ester of vinblastine. Eur | Cancer 1991;27: 1222-6.

- van Tellingen $O$, Kuijpers AV, Beijnen JH, Baselier MRP, Burghouts ITM, Nooijen WJ. Bio-analysis of vinorelbine by high-performance liquid chromatography with fluorescence detection. J Chromatogr 1992;573:328-32

- van Tellingen $\mathrm{O}$, Beijnen JH, Baurain R, ten Bokkel Huinink WW van der Woude HR, Nooijen WI. Biodetermination of $\mathrm{N}$-(deacetyl-O-4-vinblastoyl-23)-L tryptophan, a metabolite of vintriptol, by high-performance liquid chromatography with fluorescence detection. I Chromatogr 1992;574:293-8.

- van Tellingen O, Beijnen $\mathrm{JH}$, Nooijen WJ, Bult A. Pharmacology, bio-analysis and pharmacokinetics of the vinca alkaloids and semi-synthetic derivatives (review). Anticancer Res 1992;12:1699-715.
- van Tellingen O, Beijnen JH, Nooijen WJ, Bult A. Plasma pharmacokinetics of vinblastine and the investigational vinca alkaloid $\mathrm{N}$-(deacetyl-O-4-vinblastoyl-23)-L isoleucinate in mice as determined by high-performance liquid chromatography. Cancer Res 1993;53:2061-5.

- van Tellingen O, Beijnen IH, Nooijen WJ, Bult A. Plasma pharmacokinetics, disposition excretion and metabolism of vinblastine in mice as determined by high-performance liquid chromatography. Cancer Chemother Pharmacol 1993;32: 286-92.

- van Tellingen O, Kuijpers AV, Beijnen JH, Nooijen W], Bult A. Plasma pharmacokinetics, disposition excretion and metabolism of vinorelbine in mice as determined by high-performance liquid chromatography. Invest New Drugs 1993;11: $141-50$.

- van Tellingen O, Sonneveldt ALC, Beijnen JH, Nooijen W], Kettenes-van den Bosch J), Versluis $C$, et al. Plasma pharmacokinetics, disposition excretion and metabolism of vinleucinol in mice as determined by high-performance liquid chromatography. Cancer Chemother Pharmacol 1994;33: 423-34.

\section{Purine and pyrimidine metabolism: still a black box?}

- G.J. Peters and J.H. Beijnen

Pharm World Sci 1994;16(2):37-8

The Editorial in the Special Issue on Purine and Pyrimidine Metabolism contained some inaccuracies. In the right-hand column on page 38 , the fourth line from the top should have mentioned 'small black (and sometimes grey) boxes'. The generic name of 'arabinosyl-cytosine' (Table 1) is cytarabine.

\section{Purine metabolism in the heart}

\author{
Strategies for protection
}

against myocardial ischaemia

- Kris Ver Donck

Pharm World Sci 1994;16(2):69-76

In the paragraph Compounds (page 71) it was not quite clear that draflazine is identical with the I-enantiomer of R 75 231. The last sentence of the paragraph Cardiac function (page 72) should have read 'In contrast, none of the six control animals in this experiment could be weaned from cardiopulmonary bypass.' The correct page numbers for reference 21 are 1499-509.

\title{
Role of differentiation induction in action of purine antimetabolites
}

- George Weber, Yuki Hata and Noemi Prajda

Pharm World Sci 1994;16(2):77-83

In the abstract, 'difluorodeoxycytidine' should have been replaced by its generic name, gemcitabine. In Table 2, the abbreviations in the Cytogenetics column indicate the following: inv: inversion; +: gain; t: translocation; der: derivative chromosome; i: inversion; $q$ : long arm of chromosome; del: deletion. Reference 17 has now been published: Oncol Res 1993;5:1614.

On the contents page, the title of this paper was incorrect. 